\title{
Recombinant Live Vaccines to Protect Against the Severe Acute Respiratory Syndrome Coronavirus
}

\author{
Luis Enjuanes, Jose L. Nieto-Torres, Jose M. Jimenez-Guardeño, \\ and Marta L. DeDiego
}

\begin{abstract}
The severe acute respiratory syndrome (SARS) coronavirus (CoV) was identified as the etiological agent of an acute respiratory disease causing atypical pneumonia and diarrhea with high mortality. Different types of SARS-CoV vaccines, including nonreplicative and vectored vaccines, have been developed. Administration of these vaccines to animal model systems has shown promise for the generation of efficacious and safe vaccines. Nevertheless, the identification of side effects, preferentially in the elderly animal models, indicates the need to develop novel vaccines that should be tested in improved animal model systems. Live attenuated viruses have generally proven to be the most effective vaccines against viral infections. A limited number of SARS-CoV attenuating modifications have been described, including mutations, and partial or complete gene deletions affecting the replicase, like the nonstructural proteins (nsp1 or nsp2), or the structural genes, and drastic changes in the sequences that regulate the expression of viral subgenomic mRNAs. A promising vaccine candidate developed in our laboratory was based on deletion of the envelope $\mathrm{E}$ gene alone, or in combination with the removal of six additional genes nonessential for virus replication. Viruses lacking E protein were attenuated, grew in the lung, and provided homologous and heterologous protection. Improvements of this vaccine candidate have been directed toward increasing virus titers using the power of viruses with mutator phenotypes, while maintaining the attenuated phenotype. The safety of the live SARS-CoV vaccines is being increased by the insertion of complementary modifications in genes nsp1, nsp2, and 3a, by gene scrambling to prevent the rescue of a virulent phenotype by recombination or remodeling of vaccine genomes based on codon deoptimization using synthetic biology. The newly generated vaccine
\end{abstract}

\footnotetext{
L. Enjuanes ( $\varangle)$, J.L. Nieto-Torres, J.M. Jimenez-Guardeño, and M.L. DeDiego

Centro Nacional de Biotecnologia (CNB), CSIC, Campus Universidad Autonoma, Darwin 3, Cantoblanco 28049, Madrid, Spain

e-mail: L.Enjuanes@cnb.csic.es
} 
candidates are very promising, but need to be evaluated in animal model systems that include young and aged animals.

\section{The Disease}

The SARS-CoV was identified as the etiological agent of an acute respiratory disease causing atypical pneumonia and diarrhea with an average mortality of $10 \%$ [1]. SARS-CoV is a zoonotic virus that crossed the species barrier, most likely originating from bats, and has been grown in other species, notably civets [2-4]. The virus emerged in Guangdong Province, China, in late 2002, and rapidly spread to 32 countries [5-10]. After July 2003, only a few community-acquired and laboratory-acquired SARS cases have been reported (http://www.who.int/csr/sars/ en/). Of the human CoVs (HCoVs), such as HCoV-229E, HCoV-OC43, SARSCoV, HCoV-NL63, and Hong Kong University 1 (HKU1)-CoV, SARS-CoV causes the most severe disease $[11,12]$.

SARS-CoV-like viruses are circulating in bats from different continents [4, 13-15]. In addition, SARS-CoV could be used as a biological weapon, and it has been declared as a category $\mathrm{C}$ priority pathogen by the National Institute of Allergy and Infectious Diseases Biodefense (http://www.niaid.nih.gov/Biodefense/ bandc_priority.html). A defined efficacious therapy is not yet available for SARS, and the possibility of a reemergence of the virus due to the presence of a high number of bats in different continents infected with SARS-CoV ancestors is a realistic one. Therefore, the design of an effective and safe vaccine to protect against SARS is still high priority.

\section{Types of SARS-CoV Vaccines and Prospects of Protection Against SARS by Vaccination}

Several types of SARS vaccines have been developed, including inactivated viruses, subunit vaccines, virus-like particles (VLPs), DNA vaccines, heterologous expression systems, and live attenuated vaccines derived from the SARS-CoV genome by reverse genetics (for recent reviews see [16-19]). This chapter will focus on live attenuated vaccines, i.e., on the development of safe, live, recombinant vaccines based on attenuated SARS-CoV, including biosafety safeguards that can be engineered to assure attenuation.

A preliminary issue is whether previous and current attempts for developing a vaccine to protect against SARS have provided promising results. We believe that this is the case based on the results obtained with different types of vaccines [17-19]. Nevertheless, the vaccines developed so far have not been tested in humans for obvious reasons and, in addition, the animal models used to evaluate 
the experimental vaccines do not fully reproduce the clinical signs observed in the natural host. In addition, with few exceptions, the evaluation of these vaccines has been made in young animals, and it has been shown that the outcome of challenge experiments, although positive in young animals, frequently showed side effects when performed in old mice [20, 21]. Recently, animal models have been considerably improved, reproducing most of the pathology observed in humans [22, 23]. In particular, a mouse-adapted SARS-CoV model, selected after fifteen passages in mice (SARS-CoV-MA15), reproduces most clinical signs observed in human infections during the SARS epidemic in 2003, including death of infected mice. This animal model is considered the best available. Therefore, vaccine candidates developed so far may have to be reevaluated in this model using young and aged mice.

\subsection{Inactivated and Vectored Vaccines Developed to Prevent SARS}

Vaccines based on whole purified inactivated virus have the benefit of presenting a complete repertoire of viral antigens, although inactivated vaccines do not in general provide longlasting immunity. These vaccines provide good protection in mice [24], hamster [25], and partial protection in ferrets [25, 26].

In rhesus monkeys, a formaldehyde-inactivated SARS-CoV vaccine showed partial protection $[27,28]$. An inactivated SARS-CoV vaccine was also administered to humans. This vaccine was safe and induced neutralizing antibodies, but no efficacy data have been reported [29]. Overall, inactivated vaccines, based on whole purified virus, induced neutralizing antibodies, were apparently safe at least in young animal models and provided good protection.

Subunit vaccines have the advantage of their simplicity, chemical definition, and lack of potential variability [30]. In the case of SARS-CoV, a great advantage is that well-defined $\mathrm{S}$ protein domains binding the cell receptor human angiotensin converting enzyme (hACE2) have provided full immune protection [31-34]. This concept is reinforced by the observation that monoclonal antibodies specific for the receptor binding domain elicited protection in several animal models, including African green monkeys [35-41].

In addition to $\mathrm{S}$ protein-derived domains or peptides, protein $3 \mathrm{a}$, a large protein of SARS-CoV exposed on its envelope, also elicits virus neutralizing antibodies [42] and could be useful in improving subunit vaccines. Furthermore, immunity to SARS-CoV has also been demonstrated with virus-like particles (VLP) [43]. Overall, the results obtained with subunit vaccines strongly suggest that protection against SARS by vaccination is feasible.

DNA vaccines are safe and nonexpensive but, often, are not very efficient in large mammals. DNA vaccines induce SARS-CoV neutralizing antibodies and protection in mice [44-47]. 
The use of viral vectors to protect against SARS has been extensively explored. Adenovirus induced good protection in mice [25]. Modified vaccinia Ankara (MVA) provides protection in mice [35] and ferrets [48] although induction of antibody-dependent enhancement of disease (ADED) was reported. Adeno-associated virus induces long-term protection against SARS-CoV [34]. Parainfluenza virus elicits protection in hamsters and monkeys [49, 50]. Recombinant measles viruses expressing the $\mathrm{S}$ protein of SARS-CoV induces neutralizing antibodies and immune responses against SARS-CoV [51]. Newcastle disease recombinant virus expressing the $\mathrm{S}$ protein of SARS-CoV induces neutralizing antibodies in African green monkeys immunized via the respiratory tract [52]. A recombinant attenuated vesicular stomatitis virus (VSV) protects mice against SARS-CoV challenge 4 months after vaccination [53, 54]. Venezuelan equine encephalitis (VEE) virus expressing the $\mathrm{S}$ protein of SARS-CoV induces protection against challenge with virulent virus in the mouse model [20]. Overall, these results indicate that there is a very good prospect for the development of an efficacious and safe vaccine to prevent SARS. Nevertheless, there are relevant aspects that need to be improved in order to achieve a vaccine that can be fully protective and free of side effects both in young and in elderly people.

\section{The Virus}

SARS-CoV is an enveloped, single-stranded positive-sense RNA virus with a genome of $29.7 \mathrm{~kb}$ that belongs to Genus $\beta$ of the Coronaviridae [55-57] (Fig. 1a). The replicase gene is encoded within the $5^{\prime}$ two-thirds of the SARS-CoV genome, including two overlapping open reading frames (ORF) named ORFs 1a and $1 \mathrm{~b}$. The latter is translated by a ribosomal frameshift upstream of the ORF 1a stop codon [58, 59] (Fig. 1b). Translation of both ORFs in the cytoplasm of infected cells results in the synthesis of two polyproteins, pp1a and pp1ab, that are processed by two viral proteinases to yield 16 functional nonstructural proteins (nsps) $[60,61]$. These nsps are the components of the membrane-anchored replicationtranscription complex [62]. All CoVs encode species-specific accessory genes in their downstream ORFs, with a remarkably conserved order: replicase/transcriptase, spike (S), envelope (E), membrane (M), and nucleocapsid (N). The lipid bilayer envelope contains at least three proteins: $\mathrm{E}$ and $\mathrm{M}$ that coordinate virion assembly and release, and the large peplomer S (Fig 1a). This glycoprotein is located on the virion surface, conferring the virus characteristic corona shape. $\mathrm{S}$ is the main mediator of host cell attachment and entry. SARS-CoV ORFs 3a, 6, 7a, and 7b encode additional virus membrane proteins [63-67]. Other accessory proteins are $8 \mathrm{a}, 8 \mathrm{~b}$ and $9 \mathrm{~b}$. The functions for most of the accessory proteins are still unclear; however, it is known that some of these proteins influence virus-host interaction and viral pathogenesis [68-70].

For SARS-CoV, hACE2 molecule serves as a receptor [71]; CD209L has also been implicated as an alternative receptor in entry [72]. 
a

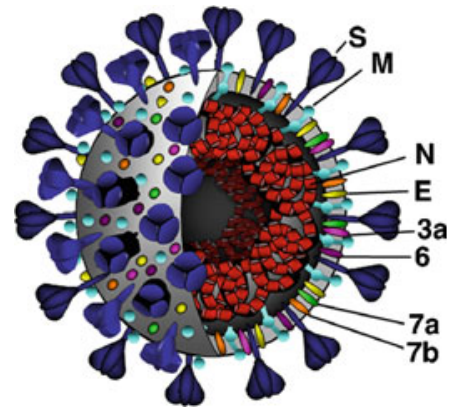

b

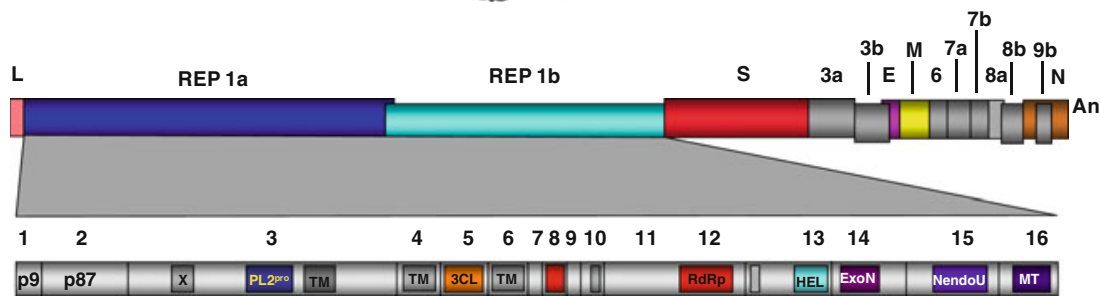

Fig. 1 SARS-CoV structure and genome organization. (a) Schematic diagram of SARS-CoV structure. $S$, spike protein; $M$, membrane protein; $E$, envelope protein; $N$, nucleoprotein; $3 a, 6,7 a$, and $7 b$, accessory structural proteins. (b) Schematic representation of SARS-CoV genome. Rep $1 a$ and $l b$, replicase genes; $3 b, 6,8 a, 8 b$, and $9 b$, nonessential genes. Other genes as in (a). In the bottom boxes, the putative functional open reading frames of the SARS-CoV replicase are indicated. $N s p$, replicase nonstructural proteins; $p 9$ and $p 87$, tentative amino-terminus replicase polypeptides; $X$, ADP-O-ribose $1^{\prime}$-phosphatase; $P L 2^{\text {pro }}$, papain-like cysteine protease $2 ; T M$, putative transmembrane domains; $3 C L$, 3C-like main protease; $R d R p$, RNA-dependent RNA polymerase; HEL, helicase; ExoN, $3^{\prime}$-to-5'-exoribonuclease; $N e n d o U$, Nidoviral uridylate-specific endoribonuclease; $M T$, putative ribose- $2^{\prime}-O$-methyltransferase

\section{Generation of Recombinant SARS-CoV Vaccines Based on the Deletion or Modification of Genes}

Live attenuated viruses have generally proven to be the most effective vaccines against viral infections. The production of effective and safe live attenuated vaccines for animal CoVs has not been satisfactory, largely because vaccine strains are insufficiently immunogenic and, in addition, may recombine, resulting in novel viruses with increased virulence [73-75]. Several groups, including ours, have described modifications to the SARS-CoV that are attenuating. These "domesticated" viruses may be useful platforms to develop inactivated or live vaccines.

In general, for RNA viruses, it is essential to develop a reverse genetic system to develop a virus with an attenuated phenotype. This is certainly the case for coronaviruses that have the largest genome known (around $30 \mathrm{~kb}$ ) for an RNA virus, increasing the technical difficulty of generating an infectious cDNA. We have developed efficient transmissible gastroenteritis CoV (TGEV) and SARS-CoV reverse genetics systems, by inserting infectious cDNA clones of these viruses into bacterial artificial chromosomes (BACs) [76-80] (Fig. 2a). In this system, the 


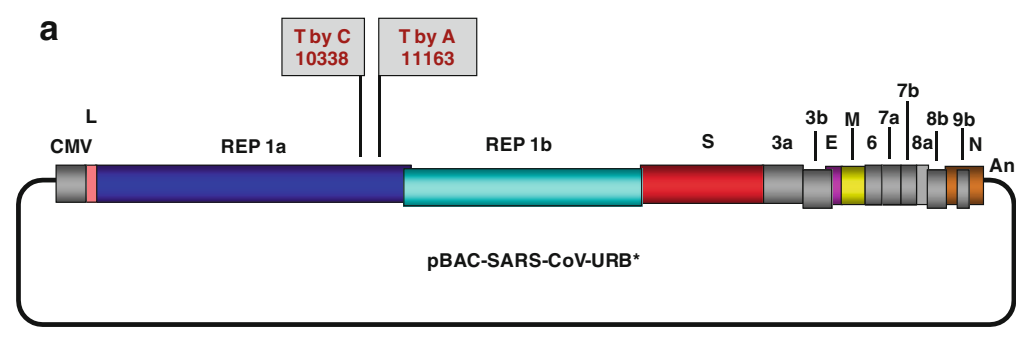

b

\begin{tabular}{ll}
\multicolumn{2}{l}{ GENES DELETED IN THE RECOMBINANT VIRUSES } \\
\hline - ENVELOPE: & E \\
- ACCESSORY: & $6,7 \mathrm{a}, 7 \mathrm{~b}, 8 \mathrm{a}, 8 \mathrm{~b}, 9 \mathrm{~b}$ \\
- COMBINATION OF BOTH: & $\mathrm{E}, 6,7 \mathrm{a}, 7 \mathrm{~b}, \mathbf{8 a}, 8 \mathrm{~b}, 9 \mathrm{~b}$
\end{tabular}

Fig. 2 Structure of the infectious SARS-CoV cDNA cloned in a bacterial artificial chromosome and the derived deletion mutants. (a) Schematic structure of the SARS-CoV infectious cDNA of the Urbani strain, cloned in a bacterial artificial chromosome (BAC). The infectious cDNA is expressed under the control of the cytomegalovirus promoter (CMV); $L$ leader; the cDNA includes genetic markers (T10338C and T11163A), introduced to differentiate the engineered clone from the wild-type Urbani strain genome; acronyms on the top of the bar indicate gene names, as in Fig. 1. (b) Table with the genes deleted in three SARS-CoV recombinant viruses. Deletion mutants without $\mathrm{E}$ gene led to viruses with attenuated phenotypes

genomic RNA is expressed in the cell nucleus under the control of a cytomegalovirus promoter (first amplification by the cellular polymerase II), with subsequent amplification in the cytoplasm by the viral RNA-dependent RNA polymerase. This reverse genetics system is highly efficient because it implies two amplification steps. In addition, cDNA stability in the BAC is very high. Soon after the BAC technology was applied to assemble an infectious coronavirus cDNA clone, alternative strategies were developed, including (1) a system to assemble a full-length cDNA construct of the TGEV genome by using adjoining cDNA subclones that have unique, flanking, interconnecting junctions [81]. Transcripts derived from the TGEV cDNA assembled using this approach can be used to derive infectious recombinant virus; (2) a system in which the cloning vector is a poxvirus. Using the genome of this poxvirus including the genome cDNA copy as a template, the viral genome is transcribed in vitro, and infectious virus is recovered from transfected cells [82]; (3) a modified procedure was described in which the coronavirus genomic RNA is transcribed inside cells using a poxvirus genome as a template. To this end, the viral genome is cloned under the control of T7 promoter, and the poxvirus DNA including the infectious cDNA is transfected into cells that are infected with a poxvirus expressing T7 polymerase [83]. The generated transcript reconstitutes an infectious $\mathrm{CoV}$.

In the case of SARS-CoV, several genes have been deleted in order to generate viruses with attenuated phenotypes. Nevertheless, deletion of one or more accessory genes did not significantly attenuate SARS-CoV [88]. Fortunately, we showed that deletion of the E gene, encoding the envelope protein, led to a viable SARS-CoV, indicating that $\mathrm{E}$ protein is not essential for virus replication. Interestingly, viruses 
lacking E protein are attenuated, grow in the lung, and are immunogenic in different animal models [79, 85-87].

Modification or deletion of other SARS-CoV genes has also been considered in the design of vaccines to prevent SARS. Some of these genes (nsp1, nsp14, S, and N) are essential for virus replication, while others $(3 a, 6,7 a, 7 b, 8 a, 8 b, 9 b)$ are nonessential for virus growth in cell culture or in vivo. The design of SARS vaccines based on deletion of SARS-CoV genes is described below. Nevertheless, most attention is given to the deletion or modification of E, nsp1, nsp2, and 3a genes.

SARS-CoV deletion mutants lacking each of ORFs $3 a, 3 b, 6,7 a$, or $7 b$ did not significantly influence in vitro and in vivo replication efficiency in the mouse model $[88,89]$. All recombinant viruses replicated to similar wild-type levels, suggesting that either the group-specific ORFs play a limited role in in vivo replication efficiency or that the mouse model used in the evaluation does not meet the requirements to discriminate the activity of group-specific ORFs in disease [88]. In fact, it was unexpected that the deletion of ORFs such as $3 \mathrm{a}, 7 \mathrm{a}$, and $7 \mathrm{~b}$ which encode structural proteins $[64,67,88,90,91]$ would show little influence on virus replication in the mouse model. Only deletion of ORF 3 a showed a minor decrease (below tenfold) in virus growth. Furthermore, deletion of combinations of genes, such as deletion of ORFs $3 \mathrm{a}$ and 3b, and ORF6, showed a 10-30-fold titer reduction in Vero cells, but showed a limited effect on virus growth in the murine model at day 2 postinfection. Moreover, the simultaneous deletion of larger combinations of group-specific genes such as $6,7 \mathrm{a}, 7 \mathrm{~b}, 8 \mathrm{a}, 8 \mathrm{~b}$, and $9 \mathrm{~b}$ has led to the production of an infectious SARS-CoV deletion mutant that propagated in cell culture with a titer similar to that of the parental wild-type virus and was not attenuated in transgenic mice that expressed the SARS-CoV receptor (hACE2) [85]. Therefore, the effect of SARS-CoV gene deletions needs to be tested in more relevant animal models.

Interestingly, the deletion of the $\mathrm{E}$ gene alone, or in combination with the removal of genes $6-9 \mathrm{~b}$, led to mutant viruses that seem to be promising vaccine candidates [79, 85-87], and is described next.

\subsection{Vaccines Based on the Deletion of E Protein}

The E gene was nonessential for the genus $\beta \mathrm{MHV} \mathrm{CoV}$ [92], although elimination of this gene from the MHV genome reduced virus growth in cell culture more than 1,000-fold. In contrast, for the group 1 TGEV coronavirus, expression of the E gene product was essential for virus release and spread. Propagation of E gene-deleted TGEV (TGEV- $\triangle \mathrm{E}$ ) was restored by providing $\mathrm{E}$ protein in trans [93, 94]. A recombinant $\mathrm{SARS}-\mathrm{CoV}$ (rSARS-CoV) that lacks the E gene, generated from a BAC (Fig. 2b), was recovered in Vero E6 cells with a relatively high titer (around $10^{6} \mathrm{pfu} / \mathrm{ml}$ ) and also from Huh-7 and CaCo-2 cells with low titers, indicating that SARS-CoV E protein is not essential for virus replication in cell culture [79]. Electron microscopy observation of Vero E6 cells infected with the SARS-CoV 


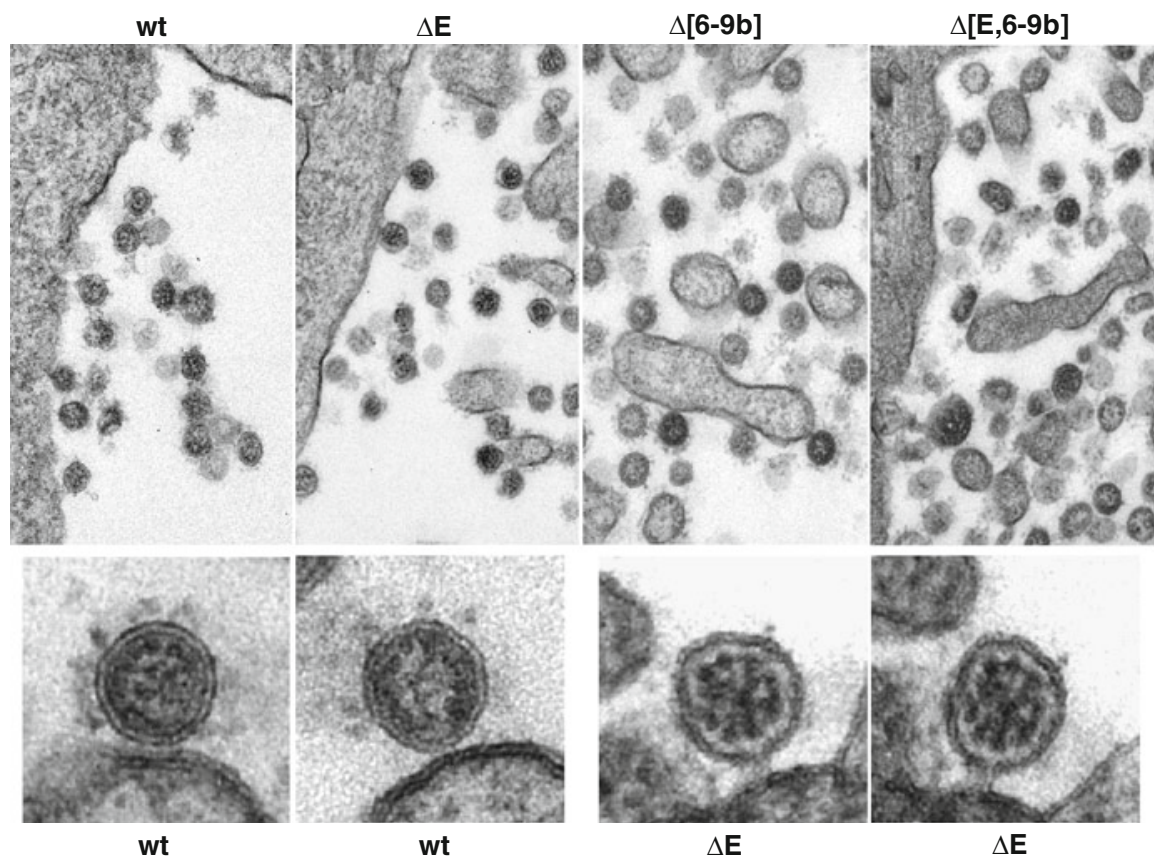

Fig. 3 Electron microscopy of SARS-CoV and envelope protein deletion mutants. (a) Extracellular viruses released from cells infected with the SARS-CoVs indicated at the top. (b) Micrographs of $w t$ and SARS-CoV- $\Delta \mathrm{E}$ mutants in the budding process. In cells infected with the wt virus, $5 \%$ of the virions in the final budding step were found bound to the cell, whereas in the $\mathrm{E}$ protein-deleted viruses, this number was increased to $16 \%$, suggesting that absence of $\mathrm{E}$ protein led to a delay in the "pinch-off step"

$w t$ or the $\Delta \mathrm{E}$ deletion mutant showed a higher efficiency of assembly and release for the $w t$ virus (Fig. 3). In this respect, SARS-CoV- $\Delta \mathrm{E}$ behaves like MHV, although SARS-CoV- $\Delta \mathrm{E}$ grows to a considerably higher titer. Vaccine viability and efficacy require the production of viruses with high titers. Interestingly, adaptation of the rSARS-CoV- $\Delta \mathrm{E}$ virus to grow in Vero cells after 16 passages led to an increase of virus titers reaching values almost identical to those displayed by the full-length virus (around $10^{7} \mathrm{pfu} / \mathrm{ml}$ ) [87]. This titer is close to those required for a competitive live attenuated vaccine.

\subsection{Evaluation of SARS-CoV-AE Vaccine Candidate in Different Animal Model Systems}

While SARS-CoV infects and replicates in several species, including mice, ferrets, hamsters, and nonhuman primates, most of these animals only develop inapparent or mild disease [95]. An ideal animal model that completely reproduces human 
clinical disease and pathological findings has not been identified. To evaluate the rSARS-CoV- $\Delta \mathrm{E}$ vaccine candidate, we have used three animal model systems: hamster, transgenic mice expressing the hACE2 receptor for human SARS-CoV, and conventional mice challenged with the mouse-adapted virus $[22,23,79,85-87$, 96-98]. These animal model systems are complementary.

The hamster model has been used to study SARS-CoV- $\Delta \mathrm{E}$ virus pathogenicity, because it demonstrates elements present in human cases of SARS-CoV infections including interstitial pneumonitis and consolidation [79, 96, 97]. The hamster model reproducibly supports SARS-CoV replication in the respiratory tract to a higher titer and for a longer duration than in mice or nonhuman primates. Virus replication in this model is accompanied by histological evidence of pneumonitis, and the animals develop viremia and extrapulmonary spread of virus [96]. Although overt clinical disease is absent, the hamster model is a useful model for the evaluation of SARS-CoV infection. Titers of recombinant SARS-CoV (rSARS$\mathrm{CoV}$ ) achieved in the respiratory tract of hamsters were similar to those previously reported for the wild-type virus [96] and were at least 100-fold higher than titers of the rSARS-CoV- $\Delta \mathrm{E}$ virus, suggesting that this mutant virus is attenuated. Histopathological examination of lungs from infected hamsters showed reduced amounts of viral antigen and pulmonary inflammation in $\mathrm{rSARS}-\mathrm{CoV}-\Delta \mathrm{E}$ infected than in rSARS-CoV infected animals, indicating that $\mathrm{rSARS}-\mathrm{CoV}-\Delta \mathrm{E}$ is attenuated in vivo [79]. In fact, reduction of SARS-CoV titers in patients has been associated with a considerable reduction in pathogenicity and increase in survival rates [99, 100]. rSARS-CoV- $\Delta \mathrm{E}$ immunized hamsters remained active following wild-type virus challenge while mock immunized displayed decreased activity [86].

The transgenic mice model is based on the production of mice expressing the hACE2, the receptor for human SARS-CoV. Transgenic mice models have been obtained in different laboratories by expressing the hACE2 under the control of different promoters $[98,101]$. These mice develop moderate respiratory disease, but overwhelming neurological disease with $100 \%$ mortality after intranasal infection with SARS-CoV. As such, they are very useful to assess attenuation and vaccine safety and efficacy. We previously showed that infection of these highly susceptible mice with rSARS-CoV- $\triangle \mathrm{E}$, or rSARS-CoV with $\mathrm{E}$ and several group-specific protein genes $6,7 \mathrm{a}, 7 \mathrm{~b}, 8 \mathrm{a}, 8 \mathrm{~b}$, and $9 \mathrm{~b}$ deleted (rSARS-CoV-[ $\Delta \mathrm{E}, 6-9 \mathrm{~b}]$ ) resulted in neither weight loss nor death, even after inoculation with very high virus doses [85].

The mouse-adapted SARS-CoV model used in the evaluation of the rSARS$\mathrm{CoV}-\Delta \mathrm{E}$ and $\mathrm{rSARS}-\mathrm{CoV}-\Delta[\mathrm{E}, 6-9 \mathrm{~b}]$ was based on the recent isolation of a SARS-CoV adapted to growth in mice or rats [22, 102, 103]. This model provided a useful system for vaccine evaluation because some strains of mice and rats infected with these viruses develop severe respiratory disease and even death. A mouse-adapted strain was isolated after 15 passages through the lungs of BALB/c mice (MA15 strain) and, unlike the parental Urbani strain of virus, intranasal inoculation with this virus results in signs of respiratory disease with substantial mortality [22]. We showed that immunization with rSARS-CoV- $\Delta \mathrm{E}$ or SARS-CoV- $\Delta[\mathrm{E}, 6-9 \mathrm{~b}]$ almost completely protected $\mathrm{BALB} / \mathrm{c}$ mice from fatal 


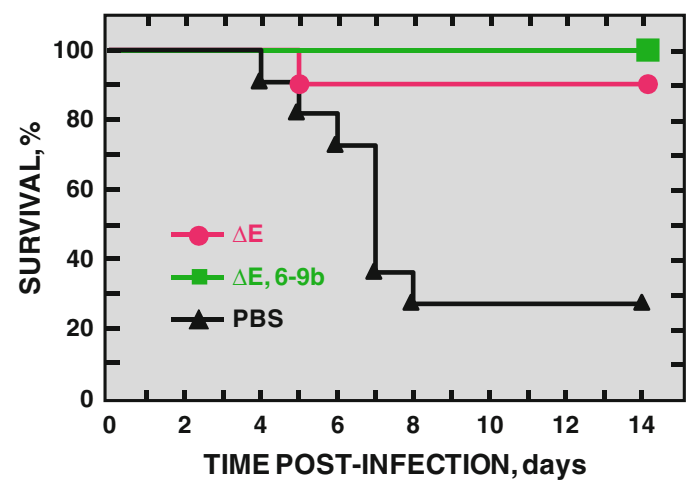

Fig. 4 Protection induced by $\Delta \mathrm{E}$ mutants against an adapted SARS-CoV in mice. Six-week-old $\mathrm{Balb} / \mathrm{c}$ mice were immunized with $12,000 \mathrm{pfu}$ of rSARS-CoV- $\Delta \mathrm{E}$ (red circles), rSARS-CoV- $\Delta$ [E,6-9b] (green squares), or PBS (black triangles) and challenged at day 21 post immunization with $1 \times 10^{5}$ pfu of the mouse adapted Urbani strain of SARS-CoV (MA15). Mice were monitored daily for survival

respiratory disease caused by mouse-adapted SARS-CoV (Fig. 4), and partly protected hACE2 transgenic mice from lethal disease [87].

In summary, the immunogenicity and protective efficacy of rSARS-CoV- $\Delta \mathrm{E}$ has been shown in the three animal model systems described above, hamsters, highly susceptible transgenic mice expressing the hACE2 receptor for human SARS-CoV and conventional mice challenged with the MA15 virus. Interestingly, both homologous and heterologous protection was observed. In fact, hamsters and hACE2 transgenic mice immunized with rSARS-CoV- $\Delta \mathrm{E}$ developed high serum neutralizing antibody titers and were protected from replication of homologous (SARS-CoV Urbani) and heterologous SARS-CoV (GD03) in the upper and lower respiratory tract $[86,87]$. The relevance of this observation is that the GD03 strain of SARS$\mathrm{CoV}$ is one of the serologically most divergent human SARS-CoV identified, in relation to the Urbani strain. In addition, it has been shown that the GD03 strain is closely related to the isolates obtained from animals and if SARS-CoV were to reemerge, it would probably have an animal origin. Despite being attenuated in replication in the respiratory tract, $\mathrm{rSARS}-\mathrm{CoV}-\Delta \mathrm{E}$ virus is an immunogenic and efficacious vaccine in hamsters and two mouse models.

\subsection{SARS-CoV E Gene Is a Virulence Gene}

E gene deletion mutants SARS-CoV- $\Delta \mathrm{E}$ and SARS-CoV- $\Delta[\mathrm{E}, 6-9 \mathrm{~b}]$ were attenuated in two animal model systems, hamster and transgenic mice, expressing the ACE-2 receptor, as indicated above. In fact, infection with both deletion mutants led to no weight loss, death, or lung immune histopathology, in contrast to infection with virulent SARS-CoV [79, 85-87] (Fig. 5). In addition, a more refined test for virus 

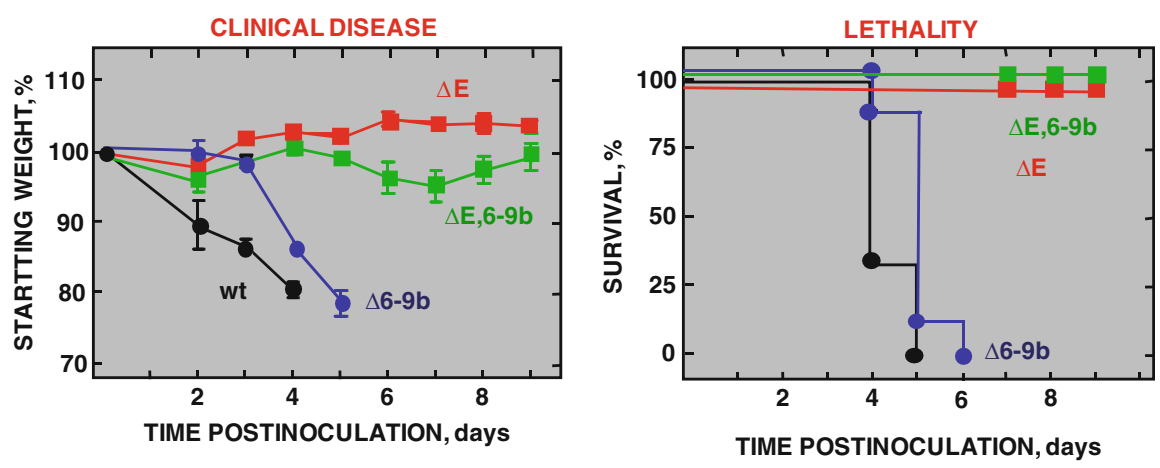

Fig. 5 Effect of SARS-CoV envelope E protein deletion on virus virulence. (a). Clinical disease. Six-week-old hACE2 transgenic mice were inoculated with 12,000 pfu of rSARS-CoV- $\Delta \mathrm{E}$ (red squares), rSARS-CoV- $\Delta[\mathrm{E}, 6-9 \mathrm{~b}]$ (green squares), wild-type rSARS-CoV (black circles), or rSARS-CoV- $\Delta[6-9 \mathrm{~b}]$ (blue circles) and monitored daily for weight loss (left) and survival (right)

virulence was performed with hamsters using the activity wheel, and no decrease of hamster activity was detected 7 days after hamster infection with the SARS-CoVs lacking the $\mathrm{E}$ gene, in contrast to those infected with a virus with full-length genome. Furthermore, rSARS-CoV- $\Delta \mathrm{E}$ did not infect the brain of infected transgenic mice, in contrast to the $w t$ virus. Overall, these data indicate that $\mathrm{E}$ is a virulence gene $[79,85]$.

The potential mechanism of E gene product in virulence has been investigated in our laboratory. We have shown that the expression of E gene drastically reduced the expression of genes involved in stress and unfolded protein responses [104]. A reduction in stress responses has been associated with a decrease in the innate and specific immune responses [105-108]. As a consequence, we have postulated that deletion of the $\mathrm{E}$ gene leads to an increased immune response to the virus, reducing its apparent pathogenicity.

\subsection{Future Improvement of rSARS-CoV-DE Vaccine}

Three complementary strategies are being applied to improve the rSARS-CoV- $\Delta \mathrm{E}$ vaccine:

\subsubsection{To Increase Virus Titers While Maintaining the Attenuated Phenotype}

To generate an efficient inactivated or live modified vaccine, virus titers need to be high in order to obtain an economically competitive vaccine. To increase virus titers, we propose a novel approach based on previous findings showing that coronavirus genomes encoding a mutated nsp $143^{\prime}-5^{\prime}$-exonuclease (ExoN) display 
a mutator phenotype [109]. The engineered SARS-CoV with a mutated or deleted E protein will be modified to include an ExoN that causes the accumulation of mutations throughout the viral genome. The mutated viruses will be passed in cell culture by infecting cells with the highest virus dilution possible. These dilutions should contain only those mutant viruses with the highest titer. Therefore, we expect that serial passages of these dilutions will select virus clones with high titers. Once the desired virus titers have been achieved, it will be confirmed that the high titer viruses are still attenuated in vivo. Virus evolution will be reverted to standard levels by replacing the mutator nsp14 by the native one using the infectious cDNA clone [110]. Selected viruses will be tested for protection as previously described.

\subsubsection{Deletion of a Second Gene That Interferes with Host-Immune Response}

We have previously shown that $\mathrm{rSARS}-\mathrm{CoV}-\Delta \mathrm{E}$ elicited protective immune responses [86, 87]. At the same time, we and others have also shown that it was possible to delete additional nonessential genes to generate viable SARS$\mathrm{CoV}[85,88]$. Some of the additionally deleted genes are involved in the inhibition of IFN activation [68, 111]. We propose to delete some of these genes and determine whether removal of any of them increases the immune response to the vaccine candidate.

\subsubsection{Construction of rSARS-CoV Mutants with Modified E Protein (E*) Eliciting Higher Immune Responses to the Virus Than rSARS-CoV Without E Protein}

SARS-CoV E protein reduced stress, unfolded protein, and immune responses to the virus. We have postulated that efforts to enhance assembly (and levels of viral protein) without diminishing the stress response, which is increased in the absence of $\mathrm{E}$, might increase immunogenicity without compromising safety. As a consequence, we propose the construction of rSARS-CoV mutants with modified $\mathrm{E}$ protein $\left(\mathrm{E}^{*}\right)$ eliciting higher immune responses to the virus than rSARS-CoV- $\Delta \mathrm{E}$. In these mutants, an $\mathrm{E}^{*}$ coding gene fully functional in virus morphogenesis is inserted within the viral genome. The approach is based on the previous identification of host proteins binding SARS-CoV E protein, influencing virus-induced stress response and the immune response to the virus. E protein ligands were identified by co-immune precipitation and mass spectrometry studies, as we have previously reported [112], and by yeast two-hybrid technologies [113]. The effect of these proteins on the stress and immune response has been identified. We propose to modify specific E protein domains, in order to prevent virus-host cell interactions that counteract the induction of a strong immune response by rSARS-CoV vaccines. 


\subsection{Live SARS-CoV Vaccines Based on Viruses Attenuated by Modification of Structural or Nonstructural Proteins}

We will focus on the modification of three SARS-CoV proteins, as previous findings on these proteins indicate that they are not fully essential for virus viability, and that their modification may lead to attenuated viruses.

\subsubsection{Modification of the Replicase nsp1 Gene}

Most of the experimental information on the influence of coronavirus replicase protein modification in attenuation has been obtained changing nsp1 and nsp2 [114-119]. In the case of SARS-CoV, it has been shown that nsp1 significantly inhibited IFN-dependent signaling by decreasing the phosphorylation levels of STAT1 while having little effect on those of STAT2, JAK1, and TYK2 [115]. A modification of SARS-CoV nsp1 (mutations R124S and K125E) resulted in a virus that replicated as efficiently as wild-type virus in cells with a defective IFN response, while its replication was strongly attenuated in cells with an intact IFN response [115]. Thus, it is likely that nsp1 mutants will lose virulence and have a reduced pathogenicity.

Alternatively, mutations or deletions in the nsp1 gene could be introduced, similar to those described in the MHV replicase $[114,116]$ that led to an attenuated CoV phenotype. These types of mutants could be investigated for their relevance in the generation of attenuated SARS-CoV phenotypes that could be tested for vaccine candidates.

\subsubsection{Modification of Replicase nsp2 Gene}

Deletion of nsp2 in MHV and SARS-CoV viruses caused $0.5-1 \log 10$ reductions in peak titers in single-cycle growth assays, as well as a reduction in viral RNA synthesis and growth $[117,119]$. These findings indicate that nsp2 is not essential for virus replication and that its deletion may lead to viruses with an attenuated phenotype. In addition, recent studies with MHV and HCoV-229E suggest that this protein may have functions in pathogenesis $[117,120]$. Therefore, nsp2 seems a promising candidate to complement the safety of a rSARS-CoV- $\Delta \mathrm{E}$ vaccine.

\subsubsection{Modification of Protein 3a}

This O-glycosylated accessory protein of 274 amino acids forms a $\mathrm{K}^{+}$-permeable channel-like structure [91]. It is not essential for growth in tissue culture cells, but deletion of the $3 \mathrm{a}$ gene leads to a small (5-10-fold reduction) virus titer reduction both in vitro and in vivo [88]. Protein 3a may also be involved in triggering high levels of proinflammatory cytokine and chemokine production [121-123], and its deletion may reduce SARS-CoV virulence. Gene $3 \mathrm{a}$ maps at a distal position from 
genes nsp1 or nsp2. Therefore, a recombination event that restores the wild phenotype for gene $3 \mathrm{a}$ and genes nsp1 or nsp2 in one event seems very unlikely.

\section{Development of a SARS-CoV Vaccine by Modification of the Transcription-Regulating Sequences}

Coronavirus transcription is regulated by highly conserved sequences preceding each gene. These transcriptional regulatory sequences (TRSs) are almost identical to sequences located at the $5^{\prime}$ end of the genome, just downstream of the leader sequence. The TRS preceding each gene encodes a complementary sequence in the newly synthesized RNA of negative polarity. These RNAs have to hybridize with the TRS located next to the leader in the process of discontinuous RNA synthesis, typical of CoVs. An alternative approach for developing safer, recombinationresistant live coronavirus vaccines has been developed by Baric's group [84]. The novel procedure involves the modification of the TRSs in a SARS-CoV vaccine strain, to a sequence incompatible with the TRS of any known circulating CoVs. It was postulated that recombinant events between $w t$ coronaviruses and TRS remodeled SARS-CoV would result in genomes containing incompatible mixed regulatory sequences that block expression of subgenomic mRNAs. Using a molecular clone, the SARS-CoV TRS network was remodeled from ACGAAC to CCGGAT [84]. This rewiring of the genomic transcription network allows efficient replication of the mutant virus, icSARS-CRG. The icSARS-CRG recombinant virus replicated to titers equivalent to $w t$ virus and expressed the typical ratios of subgenomic mRNAs and proteins. It has been shown that this vaccine candidate provides protection against challenge with virulent SARS-CoV.

\section{Potential Side Effects of SARS-CoV Vaccines}

Previous studies using animal CoVs have provided experimental evidence for humoral [124-133] and $\mathrm{T}$ cell-mediated responses to animal coronaviruses that exacerbate disease [134], as previously summarized [17]. This safety concern was increased in the case of SARS-CoV by two studies. In one report [135], antibodies that neutralized most human SARS-CoVs also enhanced virus entry mediated by two civet cat SARS-CoVs. These viruses had S glycoproteins related to the SARSCoV GD03 isolate. In a second report, it has been shown that the administration of MVA-based SARS-CoV S vaccine into ferrets, but not MVA alone, followed by live SARS-CoV challenge, resulted in enhanced hepatitis [136]. Nevertheless, these side effects have not been described in other studies with SARS-CoV in mice, hamster, ferrets, and African green monkeys [24, 35, 36, 44, 96, 137-140].

In general, immunization with vaccine candidates has resulted in the absence of side effects. Nevertheless, there are still three concerns that remain unaddressed. 
One is that specific viral proteins, such as SARS-CoV N expressed by a Venezuelan Equine Encephalitis (VEE) virus vector has resulted in enhanced immunopathology following viral challenge [20], similar to the immune pathology observed following vaccination with formalin-inactivated respiratory syncytial virus (RSV) [141-143]. A second main concern is the observation that SARS-CoV vaccines that provide protection in the absence of side effects in young mice show immunopathological complications in aged mice [20]. A third consideration is that most vaccine candidates have been tested in animal models that do not fully reproduce the clinical symptoms observed in humans, and, with one exception, no phase I clinical trials in humans have been performed. Therefore, SARS vaccine candidates would require additional rigorous clinical and immunological evaluation, using the SARS-CoV mouse-adapted virus model, and potential side effect assessment both in young and in aged animals.

\section{Future Trends to Increase Biosafety of Live Modified SARS-CoV Vaccines}

Live virus vaccine formulations should include rational approaches to minimize the potential reversion to the $w t$ phenotype and simultaneously resist recombination repair. In principle, a combination of SARS-CoV genome modifications could lead to viruses with an attenuated phenotype that could be considered safe and effective vaccine candidates.

While rSARS-CoV- $\Delta \mathrm{E}$ or the selected rSARS-CoV-E* will be attenuated, in principle, reversion to the virulent phenotype could take place by the reintroduction of the E gene into the virus, by recombination with a closely related coronavirus present in the environment. Furthermore, it cannot be excluded that compensatory mutations increasing virus fitness could cause reversion to the virulent phenotype. To minimize these possibilities, additional modifications have to be introduced into the final vaccine candidate, including the modifications of ORFs encoding proteins nsp1, nsp2, or 3a, described above. The advantage of combining deletions or mutations in the E protein with those in nsp1 or nsp2 ORFs reside in that these genes map into distal positions of the genome (more than $20 \mathrm{~kb} \mathrm{5}$ separation), making it very unlikely that a single recombination event could restore the wt virus phenotype. In addition, other creative reorganizations of the virus genome have been described that could increase SARS-CoV safety (described below).

\subsection{Gene Scrambling to Prevent the Rescue of a Virulent Phenotype by Recombination}

CoVs have a characteristic, strictly conserved genome organization with genes occurring in the order $5^{\prime}$-Pol-S-E-M-N-3'. MHV virus mutants with the genes encoding the structural proteins located in a different order were constructed, and 
it was shown that the canonical coronavirus genome organization is not essential for in vivo replication [144]. Some of the mutants showed an attenuated phenotype. Interestingly, rearrangement of the viral genes may be useful in the generation of $\mathrm{CoV}$ with reduced risk of generating viable viruses by recombination with circulating field viruses. In fact, potential recombination between viruses with different gene orders most likely will lead to nonviable viruses lacking essential genes.

\subsection{Vaccines Based on Codon Deoptimization of Viral Genome}

As a result of the degeneracy of the genetic code, all but two amino acids in the protein coding sequence can be encoded by more than one synonymous codon. The frequencies of synonymous codon used for each amino acid are unequal and have coevolved with the cell's translation machinery to avoid excessive use of suboptimal codons, which often correspond to rare or otherwise disadvantaged tRNAs $[145,146]$. This results in a phenomenon termed "synonymous codon bias" which varies greatly between evolutionarily distant species [147]. While codon optimization by recombinant methods has been widely used to improve cross-species expression, the opposite direction of reducing expression by intentional introduction of suboptimal synonymous codons has seldom been chosen [146].

De novo gene synthesis with the aim of designing stably attenuated polioviruses and SARS-CoV is a novel strategy to construct virus variants containing synthetic replacements of virus coding sequences by deoptimizing synonymous codon usage. Infection with equal amounts of poliovirus particles revealed a neuroattenuated phenotype and a striking reduction of the specific infectivity of poliovirus particles [145]. Similar attempts have been made by Baric's group to design SARS-CoV vaccines. These vaccine candidates provide protection in the mouse model system after challenge with virulent virus (Ralph Baric, personal communication). Due to the distribution effect of many silent mutations over large genome segments, codon-deoptimized viruses should have genetically stable phenotypes, and they may prove suitable as attenuated substrates for the production of vaccines.

\section{Concluding Remarks}

The production of effective and safe vaccines for animal coronaviruses, previously reported, has not been satisfactory [17, 18, 73, 74]. In contrast, the production of inactivated, subunit, vaccines based on DNA and recombinant vectors or vaccines generated by reverse genetics using SARS-CoV genomes seem more promising. Vaccine candidates need to be tested in the SARS-CoV mouse-adapted model, and in macaques, in all cases using both young and aged animals. Later, the absence of side effects and safety has to be assessed in human phase I clinical trials. 
Vaccine manufacturers have the tendency to use well-defined inactivated vaccines. Unfortunately, this approach has limited efficacy and elicits immune responses with relatively short immunological memory. A possible balance between efficacy and safety is the development of RNA replication-competent propagation-defective vaccine candidates, based on viral replicons that can generate one-cycle viruses using packaging cell lines [148].

Acknowledgements This work was supported by grants from the Comisión Interministerial de Ciencia y Tecnología (CICYT) Bio2007 - 60978, the Consejería de Educación y Cultura de la Comunidad de Madrid S-SAL-0185/06, Ministerio de Ciencia e Innovación (MICINN) Project PROFIT, CIT-010000-2007-8, Fort Dodge Veterinaria, and the European Communities (Frame VII, EMPERIE project HEALTH-F3-2009-223498, and PLAPROVA project KBBE-2008227056). MLD, JLN, and JMJ received fellowships from the Department of Education and Science of Spain. The work is also supported by a grant from the National Institutes of Health (US) RO1 AI079424-01A1, W000151845 (LE).

\section{References}

1. Peiris JS, Yuen KY, Osterhaus AD, Stohr K (2003) The severe acute respiratory syndrome. N Engl J Med 349:2431-2441

2. Woo PC, Lau SK, Li KS, Poon RW, Wong BH, Tsoi HW, Yip BC, Huang Y, Chan KH, Yuen KY (2006) Molecular diversity of coronaviruses in bats. Virology 351:180-187

3. Lau SK, Woo PC, Li KS, Huang Y, Tsoi HW, Wong BH, Wong SS, Leung SY, Chan KH, Yuen KY (2005) Severe acute respiratory syndrome coronavirus-like virus in Chinese horseshoe bats. Proc Natl Acad Sci USA 102:14040-14045

4. Li W, Shi Z, Yu M, Ren W, Smith C, Epstein JH, Wang H, Crameri G, Hu Z, Zhang H et al (2005) Bats are natural reservoirs of SARS-like coronaviruses. Science 310:676-679

5. Drosten C, Gunther S, Preiser W, van der Werf S, Brodt HR, Becker S, Rabenau H, Panning M, Kolesnikova L, Fouchier RA et al (2003) Identification of a novel coronavirus in patients with severe acute respiratory syndrome. N Engl J Med 348:1967-1976

6. Fouchier RA, Kuiken T, Schutten M, van Amerongen G, van Doornum GJ, van den Hoogen BG, Peiris M, Lim W, Stohr K, Osterhaus AD (2003) Aetiology: Koch's postulates fulfilled for SARS virus. Nature 423:240

7. Ksiazek TG, Erdman D, Goldsmith C, Zaki S, Peret T, Emery S, Tong S, Urbani C, Comer JA, Lim W et al (2003) A novel coronavirus associated with severe acute respiratory syndrome. N Engl J Med 348:1953-1966

8. Kuiken T, Fouchier RAM, Schutten M, Rimmelzwaan GF, van Amerongen G, van Riel D, Laman JD, de Jong T, van Doornum G, Lim W et al (2003) Newly discovered coronavirus as the primary cause of severe acute respiratory syndrome. Lancet 362:263-270

9. Marra MA, Jones SJM, Astell CR, Holt RA, Brooks-Wilson A, Butterfield YSN, Khattra J, Asano JK, Barber SA, Chan SY et al (2003) The genome sequence of the SARS-associated coronavirus. Science 300:1399-1404

10. Peiris JSM, Lai ST, Poon LLM, Guan Y, Yam LYC, Lim W, Nicholls J, Yee WKS, Yan WW, Cheung MT (2003) Coronavirus as a possible cause of severe acute respiratory syndrome. Lancet 361:1319-1325

11. Weiss SR, Navas-Martin S (2005) Coronavirus pathogenesis and the emerging pathogen severe acute respiratory syndrome coronavirus. Microbiol Mol Biol Rev 69:635-664

12. van der Hoek L, Pyrc K, Jebbink MF, Vermeulen-Oost W, Berkhout RJ, Wolthers KC, Wertheim-van Dillen PM, Kaandorp J, Spaargaren J, Berkhout B (2004) Identification of a new human coronavirus. Nat Med 10:368-373 
13. Graham RL, Baric RS (2010) Recombination, reservoirs, and the modular spike: Mechanisms of coronavirus cross-species transmission. J Virol 84(7):3134-3146

14. Tong S, Conrardy C, Ruone S, Kuzmin IV, Guo X, Tao Y, Niezgoda M, Haynes L, Agwanda B, Breiman RF et al (2009) Detection of novel SARS-like and other coronaviruses in bats from Kenya. Emerg Infect Dis 15:482-485

15. Muller MA, Paweska JT, Leman PA, Drosten C, Grywna K, Kemp A, Braack L, Sonnenberg K, Niedrig M, Swanepoel R (2007) Coronavirus antibodies in African bat species. Emerg Infect Dis 13:1367-1370

16. Jiang S, He Y, Liu S (2005) SARS vaccine development. Emerg Infect Dis 11:1016-1020

17. Enjuanes L, DeDiego ML, Alvarez E, Deming D, Sheahan T, Baric R (2007) Vaccines to prevent severe acute respiratory syndrome coronavirus-induced disease. Virus Res 133: $45-62$

18. Enjuanes L, DeDiego ML, Alvarez E, Capiscol C, Baric R (2008) Vaccines for severe acute respiratory syndrome virus and other coronaviruses. In: Perlman S, Gallagher TM, Snijder EJ (eds) Nidoviruses. ASM Press, Washington, pp 379-408

19. Roper RL, Rehm KE (2009) SARS vaccines: where are we? Expert Rev Vaccines 8:887-898

20. Deming D, Sheahan T, Heise M, Yount B, Davis N, Sims A, Suthar M, Harkema J, Whitmore A, Pickles R et al (2006) Vaccine efficacy in senescent mice challenged with recombinant SARS-CoV bearing epidemic and zoonotic spike variants. PLoS Med 3:2359-2375

21. Rockx B, Baas T, Zornetzer GA, Haagmans B, Sheahan T, Frieman M, Dyer MD, Teal TH, Proll S, van den Brand J et al (2009) Early upregulation of acute respiratory distress syndrome-associated cytokines promotes lethal disease in an aged-mouse model of severe acute respiratory syndrome coronavirus infection. J Virol 83:7062-7074

22. Roberts A, Deming D, Paddock CD, Cheng A, Yount B, Vogel L, Herman BD, Sheahan T, Heise M, Genrich GL et al (2007) A mouse-adapted SARS-coronavirus causes disease and mortality in BALB/c mice. PLoS Pathog 3:23-37

23. Roberts A, Lamirande EW, Vogel L, Jackson JP, Paddock CD, Guarner J, Zaki SR, Sheahan T, Baric R, Subbarao K (2008) Animal models and vaccines for SARS-CoV infection. Virus Res 133:20-32

24. See RH, Zakhartchouk AN, Petric M, Lawrence DJ, Mok CP, Hogan RJ, Rowe T, Zitzow LA, Karunakaran KP, Hitt MM et al (2006) Comparative evaluation of two severe acute respiratory syndrome (SARS) vaccine candidates in mice challenged with SARS coronavirus. J Gen Virol 87:641-650

25. See RH, Petric M, Lawrence DJ, Mok CP, Rowe T, Zitzow LA, Karunakaran KP, Voss TG, Brunham RC, Gauldie J et al (2008) Severe acute respiratory syndrome vaccine efficacy in ferrets: whole killed virus and adenovirus-vectored vaccines. J Gen Virol 89:2136-2146

26. Darnell ME, Plant EP, Watanabe H, Byrum R, St Claire M, Ward JM, Taylor DR (2007) Severe acute respiratory syndrome coronavirus infection in vaccinated ferrets. J Infect Dis 196:1329-1338

27. Lawler JV, Endy TP, Hensley LE, Garrison A, Fritz EA, Lesar M, Baric RS, Kulesh DA, Norwood DA, Wasieloski LP et al (2006) Cynomolgus macaque as an animal model for severe acute respiratory syndrome. PLoS Med 3:e149

28. Zhou J, Wang W, Zhong Q, Hou W, Yang Z, Xiao SY, Zhu R, Tang Z, Wang Y, Xian Q et al (2005) Immunogenicity, safety, and protective efficacy of an inactivated SARS-associated coronavirus vaccine in rhesus monkeys. Vaccine 23:3202-3209

29. Lin JT, Zhang JS, Su N, Xu JG, Wang N, Chen JT, Chen X, Liu YX, Gao H, Jia YP et al (2007) Safety and immunogenicity from a phase I trial of inactivated severe acute respiratory syndrome coronavirus vaccine. Antivir Ther 12:1107-1113

30. Du L, He Y, Jiang S, Zheng BJ (2008) Development of subunit vaccines against severe acute respiratory syndrome. Drugs Today (Barc) 44:63-73

31. He Y, Jiang S (2005) Vaccine design for severe acute respiratory syndrome coronavirus. Viral Immunol 18:327-332 
32. Zhou Z, Post P, Chubet R, Holtz K, McPherson C, Petric M, Cox M (2006) A recombinant baculovirus-expressed $\mathrm{S}$ glycoprotein vaccine elicits high titers of SARS-associated coronavirus (SARS-CoV) neutralizing antibodies in mice. Vaccine 24:3624-3631

33. Du L, Zhao G, Lin Y, Chan C, He Y, Jiang S, Wu C, Jin DY, Yuen KY, Zhou Y et al (2008) Priming with rAAV encoding RBD of SARS-CoV S protein and boosting with RBD-specific peptides for $\mathrm{T}$ cell epitopes elevated humoral and cellular immune responses against SARS-CoV infection. Vaccine 26:1644-1651

34. Du L, Zhao G, Lin Y, Sui H, Chan C, Ma S, He Y, Jiang S, Wu C, Yuen KY et al (2008) Intranasal vaccination of recombinant adeno-associated virus encoding receptor-binding domain of severe acute respiratory syndrome coronavirus (SARS-CoV) spike protein induces strong mucosal immune responses and provides long-term protection against SARS-CoV infection. J Immunol 180:948-956

35. Bisht H, Roberts A, Vogel L, Bukreyev A, Collins PL, Murphy BR, Subbarao K, Moss B (2004) Severe acute respiratory syndrome coronavirus spike protein expressed by attenuated vaccinia virus protectively immunizes mice. Proc Natl Acad Sci USA 101:6641-6646

36. Subbarao K, McAuliffe J, Vogel L, Fahle G, Fischer S, Tatti K, Packard M, Shieh WJ, Zaki S, Murphy B (2004) Prior infection and passive transfer of neutralizing antibody prevent replication of severe acute respiratory syndrome coronavirus in the respiratory tract of mice. J Virol 78:3572-3577

37. Rockx B, Corti D, Donaldson E, Sheahan T, Stadler K, Lanzavecchia A, Baric R (2008) Structural basis for potent cross-neutralizing human monoclonal antibody protection against lethal human and zoonotic severe acute respiratory syndrome coronavirus challenge. J Virol $82: 3220-3235$

38. Greenough TC, Babcock GJ, Roberts A, Hernandez HJ, Thomas WD Jr, Coccia JA, Graziano RF, Srinivasan M, Lowy I, Finberg RW et al (2005) Development and characterization of a severe acute respiratory syndrome-associated coronavirus-neutralizing human monoclonal antibody that provides effective immunoprophylaxis in mice. J Infect Dis 191: 507-514

39. ter Meulen J, van den Brink EN, Poon LL, Marissen WE, Leung CS, Cox F, Cheung CY, Bakker AQ, Bogaards JA, van Deventer E et al (2006) Human monoclonal antibody combination against SARS coronavirus: synergy and coverage of escape mutants. PLoS Med 3:e237

40. Sui J, Aird DR, Tamin A, Murakami A, Yan M, Yammanuru A, Jing H, Kan B, Liu X, Zhu Q et al (2008) Broadening of neutralization activity to directly block a dominant antibodydriven SARS-coronavirus evolution pathway. PLoS Pathog 4:e1000197

41. Hwang WC, Lin Y, Santelli E, Sui J, Jaroszewski L, Stec B, Farzan M, Marasco WA, Liddington RC (2006) Structural basis of neutralization by a human anti-severe acute respiratory syndrome spike protein antibody, 80R. J Biol Chem 281:34610-34616

42. Akerstrom S, Tan YJ, Mirazimi A (2006) Amino acids 15-28 in the ectodomain of SARS coronavirus 3a protein induces neutralizing antibodies. FEBS Lett 580:3799-3803

43. Lu X, Chen Y, Bai B, Hu H, Tao L, Yang J, Chen J, Chen Z, Hu Z, Wang H (2007) Immune responses against severe acute respiratory syndrome coronavirus induced by virus-like particles in mice. Immunology 122:496-502

44. Yang ZY, Kong WP, Huang Y, Roberts A, Murphy BR, Subbarao K, Nabel GJ (2004) A DNA vaccine induces SARS coronavirus neutralization and protective immunity in mice. Nature 428:561-564

45. Okada M, Okuno Y, Hashimoto S, Kita Y, Kanamaru N, Nishida Y, Tsunai Y, Inoue R, Nakatani H, Fukamizu R et al (2007) Development of vaccines and passive immunotherapy against SARS corona virus using SCID-PBL/hu mouse models. Vaccine 25:3038-3040

46. Yasui F, Kai C, Kitabatake M, Inoue S, Yoneda M, Yokochi S, Kase R, Sekiguchi S, Morita $\mathrm{K}$, Hishima $\mathrm{T}$ et al (2008) Prior immunization with severe acute respiratory syndrome (SARS)-associated coronavirus (SARS-CoV) nucleocapsid protein causes severe pneumonia in mice infected with SARS-CoV. J Immunol 181:6337-6348 
47. Wang X, Xu W, Tong D, Ni J, Gao H, Wang Y, Chu Y, Li P, Yang X, Xiong S (2008) A chimeric multi-epitope DNA vaccine elicited specific antibody response against severe acute respiratory syndrome-associated coronavirus which attenuated the virulence of SARS-CoV in vitro. Immunol Lett 119:71-77

48. Czub M, Weingartl H, Czub S, He R, Cao J (2005) Evaluation of modified vaccinia virus Ankara based recombinant SARS vaccine in ferrets. Vaccine 23:2273-2279

49. Buchholz UJ, Bukreyev A, Yang L, Lamirande EW, Murphy BR, Subbarao K, Collins PL (2004) Contributions of the structural proteins of severe acute respiratory syndrome coronavirus to protective immunity. Proc Natl Acad Sci USA 101:9804-9809

50. Bukreyev A, Lamirande EW, Buchholz UJ, Vogel LN, Elkins WR, St Claire M, Murphy BR, Subbarao K, Collins PL (2004) Mucosal immunisation of African green monkeys (Cercopithecus aethiops) with an attenuated parainfluenza virus expressing the SARS coronavirus spike protein for the prevention of SARS. Lancet 363:2122-2127

51. Liniger M, Zuniga A, Tamin A, Azzouz-Morin TN, Knuchel M, Marty RR, Wiegand M, Weibel S, Kelvin D, Rota PA et al (2008) Induction of neutralising antibodies and cellular immune responses against SARS coronavirus by recombinant measles viruses. Vaccine 26:2164-2174

52. DiNapoli JM, Kotelkin A, Yang L, Elankumaran S, Murphy BR, Samal SK, Collins PL, Bukreyev A (2007) Newcastle disease virus, a host range-restricted virus, as a vaccine vector for intranasal immunization against emerging pathogens. Proc Natl Acad Sci USA 104: 9788-9793

53. Kapadia SU, Rose JK, Lamirande E, Vogel L, Subbarao K, Roberts A (2005) Long-term protection from SARS coronavirus infection conferred by a single immunization with an attenuated VSV-based vaccine. Virology 340:174-182

54. Kapadia SU, Simon ID, Rose JK (2008) SARS vaccine based on a replication-defective recombinant vesicular stomatitis virus is more potent than one based on a replicationcompetent vector. Virology 376:165-172

55. Brian DA, Baric RS (2005) Coronavirus genome structure and replication. Curr Top Microbiol Immunol 287:1-30

56. Enjuanes L, Spaan W, Snijder E, Cavanagh D (2000) Nidovirales. In: van Regenmortel MHV, Fauquet CM, Bishop DHL, Carstens EB, Estes MK, Lemon SM, Maniloff J, Mayo MA, McGeoch DJ, Pringle CR et al (eds) Virus taxonomy. Seventh report of the international committee on taxonomy of viruses. Academic Press, New York, pp 827-834

57. Enjuanes L, Gorbalenya AE, de Groot RJ, Cowley JA, Ziebuhr J, Snijder EJ (2008) The Nidovirales. In: Mahy BWJ, Van Regenmortel M, Walker P, Majumder-Russell D (eds) Encyclopedia of Virology, 3rd edn. Elsevier, Oxford, pp 419-430

58. Brierley I, Digard P, Inglis SC (1989) Characterization of an efficient coronavirus ribosomal frameshifting signal: requirement for an RNA pseudoknot. Cell 57:537-547

59. Thiel V, Ivanov KA, Putics A, Hertzig T, Schelle B, Bayer S, Wessbrich B, Snijder EJ, Rabenau H, Doerr HW et al (2003) Mechanisms and enzymes involved in SARS coronavirus genome expression. J Gen Virol 84:2305-2315

60. Ziebuhr J (2005) The coronavirus replicase. In: Enjuanes L (ed) Coronavirus replication and reverse genetics. Springer, Berlin, pp 57-94

61. Ziebuhr J, Snijder EJ, Gorbalenya AE (2000) Virus-encoded proteinases and proteolytic processing in the Nidovirales. J Gen Virol 81:853-879

62. Stertz S, Reichelt M, Spiegel M, Kuri T, Martinez-Sobrido L, Garcia-Sastre A, Weber F, Kochs G (2007) The intracellular sites of early replication and budding of SARS-coronavirus. Virology 361:304-315

63. Ito N, Mossel EC, Narayanan K, Popov VL, Huang C, Inoue T, Peters CJ, Makino S (2005) Severe acute respiratory syndrome coronavirus 3 a protein is a viral structural protein. J Virol 79:3182-3186

64. Huang C, Ito N, Tseng CT, Makino S (2006) Severe acute respiratory syndrome coronavirus 7 a accessory protein is a viral structural protein. J Virol 80:7287-7294 
65. Huang C, Peters CJ, Makino S (2007) Severe acute respiratory syndrome coronavirus accessory protein 6 is a virion-associated protein and is released from 6 protein-expressing cells. J Virol 81:5423-5426

66. Shen S, Lin PS, Chao YC, Zhang A, Yang X, Lim SG, Hong W, Tan YJ (2005) The severe acute respiratory syndrome coronavirus $3 \mathrm{a}$ is a novel structural protein. Biochem Biophys Res Commun 330:286-292

67. Schaecher SR, Mackenzie JM, Pekosz A (2007) The ORF7b protein of SARS-CoV is expressed in virus-infected cells and incorporated into SARS-CoV particles. J Virol 81:718-731

68. Kopecky-Bromberg SA, Martinez-Sobrido L, Frieman M, Baric RA, Palese P (2007) Severe acute respiratory syndrome coronavirus open reading frame (ORF) 3b, ORF 6, and nucleocapsid proteins function as interferon antagonists. J Virol 81:548-557

69. Kopecky-Bromberg SA, Martinez-Sobrido L, Palese P (2006) 7a protein of severe acute respiratory syndrome coronavirus inhibits cellular protein synthesis and activates p38 mitogen-activated protein kinase. J Virol 80:785-793

70. Hussain S, Perlman S, Gallagher TM (2008) Severe acute respiratory syndrome coronavirus protein 6 accelerates murine hepatitis virus infections by more than one mechanism. J Virol 82:7212-7222

71. Li W, Moore MJ, Vasilieva N, Sui J, Wong SK, Berne MA, Somasundaran M, Sullivan JL, Luzuriaga K, Greenough TC et al (2003) Angiotensin-converting enzyme 2 is a functional receptor for de SARS coronavirus. Nature 426:450-454

72. Jeffers SA, Tusell SM, Gillim-Ross L, Hemmila EM, Achenbach JE, Babcock GJ, Thomas WD Jr, Thackray LB, Young MD, Mason RJ et al (2004) CD209L (L-SIGN) is a receptor for severe acute respiratory syndrome coronavirus. Proc Natl Acad Sci USA 101:15748-15753

73. Saif LJ (2004) Animal coronavirus vaccines: lessons for SARS. Dev Biol (Basel) 119:129-140

74. Cavanagh D (2003) Severe acute respiratory syndrome vaccine development: experiences of vaccination against avian infectious bronchitis coronavirus. Avian Pathol 32:567-582

75. Enjuanes L, Smerdou C, Castilla J, Anton IM, Torres JM, Sola I, Golvano J, Sanchez JM, Pintado B (1995) Development of protection against coronavirus induced diseases. A Review. Adv Exp Med Biol 380:197-211

76. Almazan F, DeDiego ML, Galan C, Alvarez E, Enjuanes L (2006) Identification of essential genes as a strategy to select a SARS candidate vaccine using a SARS-CoV infectious cDNA. Adv Exp Med Biol 581:579-583

77. Almazan F, Galan C, Enjuanes L (2008) Engineering infectious cDNA of coronavirus as bacterial artificial chromosomes. In: Cavanagh D (ed) SARS and other coronaviruses: laboratory protocols. Humana Press, Washington, pp 275-291

78. Almazan F, Gonzalez JM, Penzes Z, Izeta A, Calvo E, Plana-Duran J, Enjuanes L (2000) Engineering the largest RNA virus genome as an infectious bacterial artificial chromosome. Proc Natl Acad Sci USA 97:5516-5521

79. DeDiego ML, Alvarez E, Almazan F, Rejas MT, Lamirande E, Roberts A, Shieh WJ, Zaki SR, Subbarao K, Enjuanes L (2007) A severe acute respiratory syndrome coronavirus that lacks the E gene is attenuated in vitro and in vivo. J Virol 81:1701-1713

80. Gonzalez JM, Penzes Z, Almazan F, Calvo E, Enjuanes L (2002) Stabilization of a fulllength infectious cDNA clone of transmissible gastroenteritis coronavirus by insertion of an intron. J Virol 76:4655-4661

81. Yount B, Curtis KM, Baric RS (2000) Strategy for systematic assembly of large RNA and DNA genomes: the transmissible gastroenteritis virus model. J Virol 74:10600-10611

82. Thiel V, Herold J, Schelle B, Siddell S (2001) Infectious RNA transcribed in vitro from a cDNA copy of the human coronavirus genome cloned in vaccinia virus. J Gen Virol 82: 1273-1281

83. Casais R, Thiel V, Siddell SG, Cavanagh D, Britton P (2001) Reverse genetics system for the avian coronavirus infectious bronchitis virus. J Virol 75:12359-12369 
84. Yount B, Roberts RS, Lindesmith L, Baric RS (2006) Rewiring the severe acute respiratory syndrome coronavirus (SARS-CoV) transcription circuit: engineering a recombinationresistant genome. Proc Natl Acad Sci USA 103:12546-12551

85. DeDiego ML, Pewe L, Alvarez E, Rejas MT, Perlman S, Enjuanes L (2008) Pathogenicity of severe acute respiratory coronavirus deletion mutants in hACE-2 transgenic mice. Virology 376:379-389

86. Lamirande EW, DeDiego ML, Roberts A, Jackson JP, Alvarez E, Sheahan T, Shieh WJ, Zaki SR, Baric R, Enjuanes L et al (2008) A live attenuated SARS coronavirus is immunogenic and efficacious in golden Syrian hamsters. J Virol 82:7721-7724

87. Netland J, DeDiego ML, Zhao J, Fett C, Álvarez E, Nieto-Torres JL, Enjuanes L, Perlman S (2010) Immunization with an attenuated severe acute respiratory syndrome coronavirus deleted in E protein protects against lethal respiratory disease. Virology 399(1):120-128

88. Yount B, Roberts RS, Sims AC, Deming D, Frieman MB, Sparks J, Denison MR, Davis N, Baric RS (2005) Severe acute respiratory syndrome coronavirus group-specific open reading frames encode nonessential functions for replication in cell cultures and mice. J Virol 79:14909-14922

89. Sims AC, Burkett SE, Yount B, Pickles RJ (2007) SARS-CoV replication and pathogenesis in an in vitro model of the human conducting airway epithelium. Virus Res 133:33-44

90. Qiu M, Shi Y, Guo Z, Chen Z, He R, Chen R, Zhou D, Dai E, Wang X, Si B et al (2005) Antibody responses to individual proteins of SARS coronavirus and their neutralization activities. Microbes Infect 7:882-889

91. Lu W, Zheng BJ, Xu K, Schwarz W, Du L, Wong CK, Chen J, Duan S, Deubel V, Sun B (2006) Severe acute respiratory syndrome-associated coronavirus 3 a protein forms an ion channel and modulates virus release. Proc Natl Acad Sci USA 103:12540-12545

92. Kuo L, Masters PS (2003) The small envelope protein E is not essential for murine coronavirus replication. J Virol 77:4597-4608

93. Curtis KM, Yount B, Baric RS (2002) Heterologous gene expression from transmissible gastroenteritis virus replicon particles. J Virol 76:1422-1434

94. Ortego J, Escors D, Laude H, Enjuanes L (2002) Generation of a replication-competent, propagation-deficient virus vector based on the transmissible gastroenteritis coronavirus genome. J Virol 76:11518-11529

95. Subbarao K, Roberts A (2006) Is there an ideal animal model for SARS? Trends Microbiol 14:299-303

96. Roberts A, Vogel L, Guarner J, Hayes N, Murphy B, Zaki S, Subbarao K (2005) Severe acute respiratory syndrome coronavirus infection of golden Syrian hamsters. J Virol 79:503-511

97. Roberts A, Thomas WD, Guarner J, Lamirande EW, Babcock GJ, Greenough TC, Vogel L, Hayes N, Sullivan JL, Zaki S et al (2006) Therapy with a severe acute respiratory syndromeassociated coronavirus-neutralizing human monoclonal antibody reduces disease severity and viral burden in golden Syrian hamsters. J Infect Dis 193:685-692

98. McCray PB Jr, Pewe L, Wohlford-Lenane C, Hickey M, Manzel L, Shi L, Netland J, Jia HP, Halabi C, Sigmund CD et al (2007) Lethal infection of K18-hACE2 mice infected with severe acute respiratory syndrome coronavirus. J Virol 81:813-821

99. Chu CM, Poon LL, Cheng VC, Chan KS, Hung IF, Wong MM, Chan KH, Leung WS, Tang BS, Chan VL et al (2004) Initial viral load and the outcomes of SARS. Can Med Assoc J 171:1349-1352

100. Hung IF, Cheng VC, Wu AK, Tang BS, Chan KH, Chu CM, Wong MM, Hui WT, Poon LL, Tse DM et al (2004) Viral loads in clinical specimens and SARS manifestations. Emerg Infect Dis 10:1550-1557

101. Tseng CT, Huang C, Newman P, Wang N, Narayanan K, Watts DM, Makino S, Packard MM, Zaki SR, Chan TS et al (2007) Severe acute respiratory syndrome coronavirus infection of mice transgenic for the human Angiotensin-converting enzyme 2 virus receptor. J Virol $81: 1162-1173$ 
102. Nagata N, Iwata N, Hasegawa H, Fukushi S, Harashima A, Sato Y, Saijo M, Taguchi F, Morikawa S, Sata T (2008) Mouse-passaged severe acute respiratory syndrome-associated coronavirus leads to lethal pulmonary edema and diffuse alveolar damage in adult but not young mice. Am J Pathol 172:1625-1637

103. Nagata N, Iwata N, Hasegawa H, Fukushi S, Yokoyama M, Harashima A, Sato Y, Saijo M, Morikawa S, Sata T (2007) Participation of both host and virus factors in induction of severe acute respiratory syndrome (SARS) in F344 rats infected with SARS coronavirus. J Virol 81:1848-1857

104. DeDiego ML, Nieto-Torres JL, Enjuanes L (2010) Modulation of host stress and immune responses by severe acute respiratory syndrome coronavirus envelope E protein. Submitted

105. Asea A (2006) Initiation of the Immune Response by Extracellular Hsp72: Chaperokine Activity of Hsp72. Curr Immunol Rev 2:209-215

106. Callahan MK, Garg M, Srivastava PK (2008) Heat-shock protein 90 associates with $\mathrm{N}$-terminal extended peptides and is required for direct and indirect antigen presentation. Proc Natl Acad Sci USA 105:1662-1667

107. Moseley P (2000) Stress proteins and the immune response. Immunopharmacology 48:299-302

108. Zugel U, Kaufmann SH (1999) Role of heat shock proteins in protection from and pathogenesis of infectious diseases. Clin Microbiol Rev 12:19-39

109. Eckerle LD, Lu X, Sperry SM, Choi L, Denison MR (2007) High fidelity of murine hepatitis virus replication is decreased in nsp14 exoribonuclease mutants. J Virol 81:12135-12144

110. Almazan F, DeDiego ML, Galan C, Escors D, Alvarez E, Ortego J, Sola I, Zuñiga S, Alonso S, Moreno JL et al (2006) Construction of a SARS-CoV infectious cDNA clone and a replicon to study coronavirus RNA synthesis. J Virol 80:10900-10906

111. Frieman M, Yount B, Heise M, Kopecky-Bromberg SA, Palese P, Baric RS (2007) Severe acute respiratory syndrome coronavirus ORF6 antagonizes STAT1 function by sequestering nuclear import factors on the rough endoplasmic reticulum/Golgi membrane. J Virol 81:9812-9824

112. Alvarez E, DeDiego ML, Nieto-Torres JL, Jiménez-Guardeño JM, Marcos-Villar L, Enjuanes L (2010) The envelope protein of severe acute respiratory syndrome coronavirus interacts with the nonstructural protein 3 and is ubiquitinated. Virology 402(2):281-291

113. Konig R, Zhou Y, Elleder D, Diamond TL, Bonamy GM, Irelan JT, Chiang CY, Tu BP, De Jesus PD, Lilley CE et al (2008) Global analysis of host-pathogen interactions that regulate early-stage HIV-1 replication. Cell 135:49-60

114. Zust R, Cervantes-Barragan L, Kuri T, Blakqori G, Weber F, Ludewig B, Thiel V (2007) Coronavirus non-structural protein 1 is a major pathogenicity factor: implications for the rational design of coronavirus vaccines. PLoS Pathog 3:e109

115. Wathelet MG, Orr M, Frieman MB, Baric RS (2007) Severe acute respiratory syndrome coronavirus evades antiviral signaling: role of nsp1 and rational design of an attenuated strain. J Virol 81:11620-11633

116. Brockway SM, Denison MR (2005) Mutagenesis of the murine hepatitis virus nsp1-coding region identifies residues important for protein processing, viral RNA synthesis, and viral replication. Virology 340:209-223

117. Graham RL, Sims AC, Brockway SM, Baric RS, Denison MR (2005) The nsp2 replicase proteins of murine hepatitis virus and severe acute respiratory syndrome coronavirus are dispensable for viral replication. J Virol 79:13399-13411

118. Hertzig T, Scandella E, Schelle B, Ziebuhr J, Siddell SG, Ludewig B, Thiel V (2004) Rapid identification of coronavirus replicase inhibitors using a selectable replicon RNA. J Gen Virol 85:1717-1725

119. Gadlage MJ, Graham RL, Denison MR (2008) Murine coronaviruses encoding nsp2 at different genomic loci have altered replication, protein expression, and localization. J Virol 82:11964-11969 
120. Gu J, Korteweg C (2007) Pathology and pathogenesis of severe acute respiratory syndrome. Am J Pathol 170:1136-1147

121. Kanzawa N, Nishigaki K, Hayashi T, Ishii Y, Furukawa S, Niiro A, Yasui F, Kohara M, Morita K, Matsushima K et al (2006) Augmentation of chemokine production by severe acute respiratory syndrome coronavirus $3 \mathrm{a} / \mathrm{X} 1$ and $7 \mathrm{a} / \mathrm{X} 4$ proteins through $\mathrm{NF}-\mathrm{kappaB}$ activation. FEBS Lett 580:6807-6812

122. Law HK, Cheung CY, Ng HY, Sia SF, Chan YO, Luk W, Nicholls JM, Peiris JS, Lau YL (2005) Chemokine up-regulation in SARS-coronavirus-infected, monocyte-derived human dendritic cells. Blood 106:2366-2374

123. Narayanan K, Huang C, Makino S (2008) SARS coronavirus accessory proteins. Virus Res 133:113-121

124. O'Connor A, Martin SW, Nagy E, Menzies P, Harland R (2001) The relationship between the occurrence of undifferentiated bovine respiratory disease and titer changes to bovine coronavirus and bovine viral diarrhea virus in 3 Ontario feedlots. Can J Vet Res 65: 137-142

125. Pedersen NC, Boyle JF, Floyd K, Fudge A, Barker J (1981) An enteric coronavirus infection of cats and its relationship to feline infectious peritonitis. Am J Vet Res 42:368-377

126. Weiss RC, Dodds WJ, Scott FW (1980) Disseminated intravascular coagulation in experimentally induced feline infectious peritonitis. Am J Vet Res 41:663-671

127. Porterfield JS (1986) Antibody-dependent enhancement of viral infectivity. Adv Virus Res $31: 335-355$

128. Vennema H, de Groot RJ, Harbour DA, Dalderup M, Gruffydd-Jones T, Horzinek MC, Spaan WJ (1990) Early death after feline infectious peritonitis virus challenge due to recombinant vaccinia virus immunization. J Virol 64:1407-1409

129. Weiss RC, Scott FW (1981) Antibody-mediated enhancement of disease in feline infectious peritonitis: comparisons with dengue hemorrhagic fever. Comp Immunol Microbiol Infect Dis 4:175-189

130. Corapi WV, Darteil RJ, Audonnet J-C, Chappuis GE (1995) Localization of antigenic sites of the $\mathrm{S}$ glycoprotein of feline infectious peritonitis virus involved in neutralization and antibody-dependent enhancement. J Virol 69:2858-2862

131. Corapi WV, Olsen CW, Scott FW (1992) Monoclonal antibody analysis of neutralization and antibody-dependent enhancement of feline infectious peritonitis virus. J Virol 66: 6695-6705

132. Olsen CW, Corapi WV, Ngichabe CK, Baines JD, Scott FW (1992) Monoclonal antibodies to the spike protein of feline infectious peritonitis virus mediate antibody-dependent enhancement of infection of feline macrophages. J Virol 66:956-965

133. Olsen CW, Corapi WV, Jacobson RH, Simkins RA, Saif LJ, Scott FW (1993) Identification of antigenic sites mediating antibody-dependent enhancement of feline infectious peritonitis virus infectivity. J Gen Virol 74:745-749

134. Zhong X, Yang H, Guo ZF, Sin WY, Chen W, Xu J, Fu L, Wu J, Mak CK, Cheng CS et al (2005) B-cell responses in patients who have recovered from severe acute respiratory syndrome target a dominant site in the S2 domain of the surface spike glycoprotein. J Virol 79:3401-3408

135. Yang ZY, Werner HC, Kong WP, Leung K, Traggiai E, Lanzavecchia A, Nabel GJ (2005) Evasion of antibody neutralization in emerging severe acute respiratory syndrome coronaviruses. Proc Natl Acad Sci USA 102:797-801

136. Weingartl H, Czub M, Czub S, Neufeld J, Marszal P, Gren J, Smith G, Jones S, Proulx R, Deschambault $\mathrm{Y}$ et al (2004) Immunization with modified vaccinia virus Ankara-based recombinant vaccine against severe acute respiratory syndrome is associated with enhanced hepatitis in ferrets. J Virol 78:12672-12676

137. Martina BE, Haagmans BL, Kuiken T, Fouchier RA, Rimmelzwaan GF, Van Amerongen G, Peiris JS, Lim W, Osterhaus AD (2003) SARS virus infection of cats and ferrets. Nature 425:915 
138. He Y, Li J, Li W, Lustigman S, Farzan M, Jiang S (2006) Cross-neutralization of human and palm civet severe acute respiratory syndrome coronaviruses by antibodies targeting the receptor-binding domain of spike protein. J Immunol 176:6085-6092

139. McAuliffe J, Vogel L, Roberts A, Fahle G, Fischer S, Shieh WJ, Butler E, Zaki S, St Claire M, Murphy B et al (2004) Replication of SARS coronavirus administered into the respiratory tract of African Green, rhesus and cynomolgus monkeys. Virology 330:8-15

140. Qin E, Shi H, Tang L, Wang C, Chang G, Ding Z, Zhao K, Wang J, Chen Z, Yu M et al (2006) Immunogenicity and protective efficacy in monkeys of purified inactivated Vero-cell SARS vaccine. Vaccine 24:1028-1034

141. Hancock GE, Speelman DJ, Heers K, Bortell E, Smith J, Cosco C (1996) Generation of atypical pulmonary inflammatory responses in $\mathrm{BALB} / \mathrm{c}$ mice after immunization with the native attachment $(\mathrm{G})$ glycoprotein of respiratory syncytial virus. J Virol 70:7783-7791

142. De Swart RL, Kuiken T, Timmerman HH, van Amerongen G, Van Den Hoogen BG, Vos HW, Neijens HJ, Andeweg AC, Osterhaus AD (2002) Immunization of macaques with formalin-inactivated respiratory syncytial virus (RSV) induces interleukin-13-associated hypersensitivity to subsequent RSV infection. J Virol 76:11561-11569

143. Kim HW, Canchola JG, Brandt CD, Pyles G, Chanock RM, Jensen K, Parrott RH (1969) Respiratory syncytial virus disease in infants despite prior administration of antigenic inactivated vaccine. Am J Epidemiol 89:422-434

144. de Haan CAM, Volders H, Koetzner CA, Masters PS, Rottier PJM (2002) Coronavirus maintain viability despite dramatic rearrangements of the strictly conserved genome organization. J Virol 76:12491-12502

145. Mueller S, Papamichail D, Coleman JR, Skiena S, Wimmer E (2006) Reduction of the rate of poliovirus protein synthesis through large-scale codon deoptimization causes attenuation of viral virulence by lowering specific infectivity. J Virol 80:9687-9696

146. Gustafsson C, Govindarajan S, Minshull J (2004) Codon bias and heterologous protein expression. Trends Biotechnol 22:346-353

147. Plotkin JB, Robins H, Levine AJ (2004) Tissue-specific codon usage and the expression of human genes. Proc Natl Acad Sci USA 101:12588-12591

148. Enjuanes L, Sola I, Alonso S, Escors D, Zuñiga S (2005) Coronavirus reverse genetics and development of vectors for gene expression. In: Enjuanes L (ed) Coronavirus replication and reverse genetics. Springer, Berlin, pp 161-197 